\title{
Construction Of Shari'ah Entrepreneurship Values In Local Wisdom Perspective Of Gayo Community
}

\author{
Abdiansyah Linge ${ }^{1}$, Amiur Nuruddin ${ }^{2}$, Ahmad Qorib $^{3}$ \\ ${ }^{1}$ State Islamic University of North Sumatera Indonesia \\ ${ }^{2}$ State Islamic University of North Sumatera Indonesia \\ ${ }^{3}$ State Islamic University of North Sumatera Indonesia
}

\begin{abstract}
Constructing shari'ah Entrepreneurship concept or values based on local wisdom of Gayo communities aimed to construct shariah entrepreneurship values sourced from society's behavior pattern named culture, to create social interest propulsion to conduct distribution and production economy activities by entrepreneurship values. This research used micro ethnography approach by developing Gayonese custom ethnolinguistic as shari'ah entrepreneurship Concept. Integration of spiritual values, planning, sustainability of economy resources and Moral is shariah entrepreneurship concept in Gayo local wisdom.
\end{abstract}

Keywords: Construction, Value, Shariah Entrepreneurship, Custom

\section{INTRODUCTION}

Economy development bounded by three economy practices, they are production, distribution and consumption. Economy development is multidimensional process involving basic changes in social structure, social behavior and institution ${ }^{1}$. Therefore, communities can participate in economy by the availability of job vacancy (full employment), everyone might has equal abilities (equal productivity, equal access), and each behavior act rationally (efficiently).

Culture becomes variable forming behavior and community views in economy practices and entrepreneurship activities as well. Behavior is formed from Idea, thought becomes custom inherited from previous generation, therefore the interest toward entrepreneurship activities also related to the idea, the thought that becomes driving force of behavior formation in a community.

Most of Aceh Tengah society is Gayo tribe. Economy practices of Gayo communities are dominated by agricultural industry sector, especially Coffee commodity. Coffee is a major income source of Gayonese. It is caused by farming culture inherited from previous generation of community. Multiplier effect from agricultural (coffee) and plantation product appoint economy development in Aceh Tengah. The issue in economy activity is the absence of creativity and innovation process in agriculture product to increase value adds of the product, to create employment, and to set new market to increase selling value of commodity. Such problems are part of special studies in this research aimed to increase community interest in entrepreneurship activities by identifying entrepreneurship values in Gayo local wisdom.

\section{BACKGROUND}

Entrepreneurship is a part of social sciences studying about production, distribution and consumption of goods and services, and becoming a certainly independent discipline because it has characteristics as follows:

1. It is a body of knowledge consists of theory, concept and scientific method

2. It has two concept; venture start-up and venture growth

3. It has its own object of study, namely the ability to create a new and different thing.

4. Entrepreneurship creates employment. A tool to create business equity and income or prosperity ${ }^{2}$

Entrepreneur is who organizes, manages and assumed the risk of business of enterprise ${ }^{3}$. Drucker defined entrepreneurship as an effort to create a new and unique goods and services. While Zimmerer stated that entrepreneurship is a process of creativity and innovation implementation to create business opportunity. The main step done by entrepreneur is to make business plan. Planning is a blue print about motivation, goal, strategy, operation, market opportunity possibly attained, and management ability of business ${ }^{4}$.

Based on feasibility study, decision taken by entrepreneur contains failure or success potency, therefore, there are two alternatives taken by entrepreneur, namely risk-taking alternative and conservative alternative. The alternative choice depending on: 
1. The attraction of each alternative;

2. Ready to get loose;

3. Relative possibility of success and failure ${ }^{5}$.

A confident entrepreneur is brave to take risks. Risk with accountable calculation, optimism, and difficult- challenge like but achievable will develop good entrepreneur character ${ }^{6}$.

Innovation, creativity and flexibility values are originality elements needed by a good entrepreneur. A scientist said creativity definition as follow:

"Sometimes creativity involves generating something from nothing. However, creativity is more likely to result in collaborating on the present, in putting old things together in new ways, or in taking something away to create something simpler or better ${ }^{7}$.

The definition concluded that creativity is producing new things and has economy value to meet human needs. Creative thinking will develop future-oriented person and improve better condition by revising old ways to be new ways. It makes things to be easier and better. A good entrepreneur possesses creativity in developing undertaken economic effort.

Islam sees entrepreneurship as a part of works. In economic perspective, working is an effort done by someone to meet physical and spiritual needs. Islamic thought really support its Ummah to have a role in business activity. In accordance to Allah words in At-Taubah verse 105:

And say (O Muhammad) "Do deeds! Allah will see your deeds, and (so will) His Messenger and the believers. And you will be brought back to the All-Knower of the unseen and the seen. Then He will inform you of what you used to do."

The obligation of working is also stated in another verse, Allah said:

Then when the (Jumu'ah) Salat (prayer) is finished, you may disperse through the land, and seek the Bounty of Allah (by working, etc.), and remember Allah much, that you may be successful (Q.S. Al Jumuah: 10)

Hadits also motivates the development of entrepreneurship spirit, Muhammad SAW said: Indeed, the best livelihood is a trader (entrepreneur). (HR. Baihaqy). Islam has high entrepreneurship spirit. The prophet, in most literature, is an entrepreneur, so do his friends, even they trade internationally.

Business practices in Al Quran represented by the word At-Tijaarah. In Al Quran, there are nine repetitions of the word tijarah, six of them refer to economic activity meanings ${ }^{9}$. There are values that must be implemented by a moslem entrepreneur in performing business activities. The available values of Al Quran are as a booster value of entrepreneur behavior, it becomes behavior philosophy of faithful and cautious moslem entrepreneur, therefore trading or doing business activity always directed to the philosophy values. As what is written in An-Nisa verse 29, in which it said that moslem entrepreneur give priority on righteousness (leaving bad ways) and fair business agreement (an taraddin minkum) in performing business activity.

"O you who believe! Eat not up your property among yourselves unjustly except it be a trade amongst you, by mutual consent. And do not kill yourselves (nor kill one another). Surely, Allah is Most Merciful to you." (Q.S. An Nisa: 29)

Definition of tijaarah has two meanings, first; as pengabdian between human and the creator. When human as a slave practices Allah's command by doing ibadah mahdah, it described the human action as having business with Allah. Second; tijaarah generally means business practices among human (muamalah). Putting priority on fairness in business is a value in tijaarah (Al- Baqarah; 282, An Nisa; 29 and an Nur: 37). It explained about buying and selling mechanism, debts, lease, and other transaction. In the verse, there are also accountability, notary and Islamic business values in general.

Motive of entrepreneur practice is worship, when an entrepreneur implements business activity by always remembering Allah, doing Shalat, paying Zakat. It Means that all implemented economic behavior must be integrated with worship to Allah SWT and always remember Allah. This value is a regulation for moslem entrepreneur in doing business activities to be always doing kindness and keeping away a bad activities in all aspects of business (an Nisa: 29).

Business purpose in Al Quran is to get two profits. Namely worldly and hereafter profits. Business in Al-Quran is categorized into three, they are: profitable business, harm business and achievement maintenance (reward and punishment). Here, Al Quran highlighted that all human deeds are under Allah monitor, therefore all deeds done have consequences (merit-sin) ${ }^{10}$.

\section{OBJECTIVES}

Researcher identified entrepreneurship values in Gayonese local wisdom that formed values system of Gayo custom and as booster value of society behavior in entrepreneurship activity. It is a main study of the research because the value is a foundation to construct Islamic entrepreneurship concept. The obtained data by identifying values in occasions and dialogues found in Gayo society (ethno linguistically) that will be studied is I langit bintang pitu, I bumi kal pitu mata. 
Ethno-linguistically, from sentence I langit bintang pitu, I bumi kal pitu mata, linguistically it means "in the sky is seven stars, in the earth is muk with seven eyes". In terminology, it means there is relevancy between sky power (power of God) and the effort done in the world. The integration between world and hereafter is the implied meaning of this philosophy. From the interpretation, it can be understood that entrepreneurship activities is bounded with conditions possessed by the sky power, namely: religion. Religious norms serve as a basis in implementing entrepreneurship activities, therefore the activities implemented by human in the world must suit the religious norms.

Religion rules human to manage natural resources offered by God to meet human life needs. Various natural resources is given by God to meet life needs and to develop better life. However, religion also set to keep natural resources sustainability by not exploiting it excessively and not destroy the nature. The balance between using natural resource and preserving its existence must be implemented to keep the sustainability of nature life.

Kal Pitu mata, kal (bowl) represent fairness, kal is used as a gauges of rice. Fairness is a universal value that has social dimension. Fairness is moral aspect forming someone's behavior. Without fairness in economy activity, there will be tyranny and it harm particular group or person. Moral has close relationship with fairness. Referring to ethnolinguistic of Gayonese culture, fairness is a must high-raised value, particularly in economy activity. Therefore entrepreneurs have to raise fairness value to create more good-moral and goodcharacter entrepreneur behavior.

While, Bintang Pitu means beginning business or starting economy activity. Star is an object that is always referred as tools showing time and direction. It is time calculation or standard using stars in the sky at night which is based on constellations. It is also used as a decider of planting season for farmers.

Time decision to start economy activities is related closely to planning. An economic activity must be started with accurate planning to avoid loose. For example, farmers start planting season by using constellation, based on local wisdom of gayo community, planting season can take place when it was decided by kejurun belang (village apparatus) as one of apparatus of sarak opat (village gevernmentship) through studies of seasons change. If the communities disobey the rule, they will get customary law and they might be lost caused by the incompatibility with season change (ex; harvesting in rain season might decrease the productivity).

Economic activity integrates implemented efforts and spiritual value believed. Fairness principle become a frame in implementing economic activity in order to have social dimension in form of moral or good character. The implemented economic activity must not harm particular group or person.

In addition, implemented economic activity or economy effort must be relevant with good planning. Plan will equip the implemented activity, because a good plan will make the implementation easier. Through a plan, motivation, mechanism and purposes of implementing economy activity will be acquired by entrepreneur.

\section{PROCEDURE}

This research is a study about shari'ah entrepreneurship value in gayonese culture perspective using qualitative approach in form of micro ethnography. It analyze the application of entrepreneurship values in local genius system or Gayo community custom. This research is focused on the field related to entrepreneurship values to construct shari'ah entrepreneurship by seeing phenomenon from Gayo ethno linguistic.

Analysis steps are run through some stages:

1. Make domains and input it into list. The process is implemented to limit entrepreneurship values acquired from Al Quran and economics fields by categorizing data related with the decided domain then turn it into research component;

2. Decide data (component) of entrepreneurship values in local wisdom of Gayonese custom;

3. Stage of developing taxonomy based on component developed.

4. Constructing Shariah entrepreneurship concept based on values possessed in local wisdom of gayonese custom.

Based on research procedure above, the purpose to construct entrepreneurship concept based on local wisdom values can be realized.

\section{RESULTS}

Ethnolinguistically, the sentence "I langit bintang pitu, I bumi kal pitu mata" contains entrepreneurship value becoming entrepreneurship principle in doing economic activities, the values are:

1. Spiritualism

2. Planning

3. Economic Resource Sustainability

4. Morality (Fairness)

Spiritualism is a motivational value of entrepreneurs in implementing economic activities by integrating both worldly and ukhrawi (hereafter) dimension. It means believing that their works affect the life in 
here after. Therefore entrepreneurs' behavior in creating and developing economic effort is in line with religion rule. Entrepreneur behavior that is suitable with religion rule will create religious (spiritual) entrepreneur. Referring religion as guidelines in economic activities will bring profits not only worldly but also hereafter (Blessed).

The second value is planning. Planning is a form of professionalism in doing economic activities. Economic activities that are motivated by spiritualism and applied in an economic planning might establish mechanism of entrepreneurship activities that are appropriate with economic needs and might not disobey religion's rule. Good planning will drive entrepreneurship activities to the targeted goals.

Economic resource sustainability is value implemented in the process of entrepreneurship activities. Production and distribution process do not only exploit the available economic resources, but also keep and preserve the resources to keep it sustainable to be utilized by next generations.

The last value is morality. Spiritualistic motivation, professional planning, and prioritizing-social-needs process will form entrepreneurs characters who are religious, professional, social needs oriented. It will create moral-have entrepreneurs. Moral is a main asset in implementing business activities. It is also reflected by the prophet Muhammad SAW, in which His main capital is honesty, even he was called al-Amiin. Moral might develop trustworthy character. Moral or good character including fairness, trustworthiness, and professional transparency will form good entrepreneur.

\section{CONCLUSION}

Based on above studies, entrepreneurship must be implemented based on values available in local wisdom. The custom will create values, ideas, thoughts forming entrepreneurship behavior. Entrepreneurship integrating spiritualistic values with entrepreneurship will form entrepreneurship spiritualistic concepts that still can be studied further. Entrepreneurship behavior also prioritizes the sustainability of economic resources in welfare perspective.

Based on ethnolinguistic of Gayonese custom, planning is the first step implemented by entrepreneur in doing economic activity by understanding analyzed potency, idea and purpose to decide whether it is implementable or not. Some aspects that might be analyzed are shariah, social, management, market and product.

Last but not least, the conclusion in this study come up with ethic aspect (moral). Consumer orientation is not merely gain oriented, but to set partnership with the consumer based on trustworthiness. Product and service quality delivered with moral value will create satisfaction of consumer. Creating convenience by giving real and complete information about a good or service will set trustworthiness. Strategy of market driven implementation based on moral will give value-added on the success of strategy implementation.

\section{REFERENCES}

[1] Michel Todaro, Economic Development (Singapore: Longman Singapore Publisher, 1994). In: Euis Amalia, Keadilan Distributif dalam Ekonomi Islam (Jakarta: PT. RajaGrafindo Persada, 2009)

[2] Soeharto Prawirakusumo, Peranan Perguruan Tinggi dalam Menciptakan Wirausahawan. (Jatinangor: PIBI-IKOPIN, 1997)

[3] M. Faizal P. Rameli, dkk, The Characteristics of Muslimpreneurs from the view of Muslim Scholars and Academician, International Journal of Teaching and Education, Vol. II (No. 2), ISSN 2336-2022 ( IACIS, UiTM Melaka; 2FEM, Universiti Sains Islam Malaysia; 3FEA, UniversitiMalaya).

[4] Peggy Lambing,. C,R, Kuehl, Intreprenuership, (New Jersey: Prantice Hill, 2000).

[5] Meredith. G.G, Kewirausahaan; Teori dan Praktik (Jakarta: Pustaka Binaman Presindo, 1996).

[6] Meredith. G.G, Kewirausahaan; Teori dan Praktik (Jakarta: Pustaka Binaman Presindo, 1996).

[7] Zimmerer, T.W,. N.M. Scarborough. Entreprenuership and the new Venture Formation (New Jersey: Prantice Hall International. Inc, 1996).

[8] Alquran al Karim, Mushaf Ustmani

[9] Amiur Nuruddin, Bisnis Islam Dalam Perspektif Alquran dan As-Sunnah, International Conference of Islamic Development ( $7^{\text {th }}$ ACID) Medan, Sumatera Utara, 12 Juni 2015.

[10] Muhammad Djakfar, Agama, Etika dan Ekonomi; Wacana Menuju Pengembangan Eknomi Rabbaniyah (Malang; UIN Malang Press, 2007). 